\title{
Cultural Capital in the Economic Field: A Study of Relationships in an Art Market
}

\author{
Lars Vigerland ${ }^{1} \cdot$ Erik A. Borg $^{1}$
}

Published online: 12 June 2017

C The Author(s) 2017. This article is an open access publication

\begin{abstract}
In this study of an economic field and its relationships to a cultural field, we apply Pierre Bourdieu's central concepts of economic capital, cultural capital, symbolic capital and field, and thus follow in a tradition that at the outset was considered to be post-structuralism, but which by Bourdieu later has been brought into the realm of realism. We have mapped relationships between the actors and thus the field structures that these relationships entail. The fields in which a segment of an art world is operating is represented in multi-dimensional figures which illustrate relationships and bonds between the different categories of organizations. Some of the business actors we have studied are engaging in cultural activities with a great deal of autonomy, others are connected to the cultural field in less active ways. In participating in the cultural field they are in different ways and to different extents accumulating symbolic capital including prestige and honor. The method we have applied is multiple correspondence analysis which was frequently used by Bourdieu.
\end{abstract}

Keywords Bourdieu · Correspondence analysis · Cultural capital · Economic capital · Field · Multiple correspondence analysis · Symbolic capital

\section{Introduction}

The main purpose of this article is to analyze a business field and its interaction and relationships to actors in an art market and to art, thus an art field. We have studied the market for art in the Stockholm region. In doing so we have applied central aspects of Pierre Bourdieu's concepts of field and capital. Significant aspects of field and capital theory can be found in Bourdieu's Distinction (1986a) and significant aspects of cultural theory can be found in Bourdieu's two books The Field of Cultural Production (1983) and in The Rules of Art (1996a). These books represent central parts of Bourdieu's theory of understanding field,

Erik A. Borg

erik.borg@sh.se

1 School of Business, Department of Social Sciences, Sodertorn University, Alfred Nobels Alle 9, 14189 Huddinge, Sweden 
capital and media production. Cultural production entails in this work a very broad understanding of culture in line with classical sociology which entails all social science including all expressive-aesthetic, literature and art (Hesmondhalgh 2006, pp. 211-212). With this broad definition of culture in mind we have set out to interpret positions of actors in a specific business field and in a cultural field, and the degree to which they are autonomous of each other. In doing so we are applying the methodology of correspondence analysis to a great extent used and developed by Bourdieu. In his research, Bourdieu developed and used multiple correspondence analysis to produce a range of figures that are associated with central concepts of culture.

Bourdieau is relevant to our way of study as his works "blend the full range of sociological styles, from painstakingly ethnographic accounts to sophisticated mathematical modelling to highly abstract metatheoretical and philosophical arguments" (Wacquant 1989, p. 27). Again, the use of mathematics is not positivist in nature (Merquior 1985). In his early work Bourdieau seeks to solve the conflict between objectivism and subjectivism through a "structuralist constructivism or a constructivist structuralism" (Bourdieu and Wacquant 1992, p. 11). Researchers like Giddens (1984) and Archer (2000) later place the research represented by Bourdieu firmly in a realist tradition or by Fowler (1996) more specifically within enriched realism, not least in the way he addresses the duality between agentic and structural explanations of social phenomena. An essential contribution to management and organization research can be drawn from Bourdieu's writings as it is: (i) offering a conceptual framework for multilevel research agenda in organization and management studies, (ii) is presenting an epistemological and methodological framework for tackling issues of reflexivity in the research process, and (iii) is proposing a methodological and epistemological way to overcome the dualism between structure and agency, and objectivism and subjectivism (Özbilgin and Tatli 2005. We have applied Bourdieu's methodology as it is able to connect the concepts of field, cultural-, economic- and symbolic capital, and display these connections in graphical forms. This methodology is more thoroughly described in the methodology section of this article.

The aim of this study expressed in more detail is to analyze profit-oriented corporate relationships and linkages with non-profit oriented organizations working with art, and also to analyze profit-oriented corporate possessions of art. In doing so we are working in the intersection between art and business on the one hand and aesthetics and science on the other. Our analysis has been carried out with the theoretical concepts of Bourdieu. The term organizations is used as a broader term for the actors involved with art, as these actors are of diverse organizational nature, such as established businesses, foundations, trusts, institutions.

\section{Arts Marketing}

Arts marketing has over the recent years developed as a separate sub-discipline of marketing where some of the theoretical underpinnings are different from mainstream marketing. Consumers' aesthetic experiences can be examined within philosophical, psychological and social science perspectives (Charters 2006). Businesses and corporations have discovered art marketing as an opportunity for corporate social development. At the same time, art is representing possibilities for social inclusion, community development and urban regeneration (Kerrigan et al. 2009). This dual role of art has eloquently been analyzed by Schroeder (2006) in a study 
of art as a commodity culture and simultaneously as an alleviated conception of aesthetics and art. A distinction can be made between the integration of aesthetics into everyday consumption and the construction of meaning and identity. It has been pointed out that commercial influencers on popular culture increase as aesthetic images make their way into everyday consumption (Venkatesh and Meamber 2008).

Aesthetic discourse in contemporary studies has come to possess different meanings. In studies of aesthetics in everyday consumption practices and patterns, a political economy approach to arts marketing has been shown to be constructive (Joy and Sherry 2004). Art can be used to create an atmosphere in an office setting and art is consumed by corporations to create an image in the workplace. The atmosphere influences people subtly at an emotional level beyond mere rational understanding (Biel-Missal 2013). Our study uses a sociological approach to art and consumption and looks at corporations' use of art in order to increase their cultural and economic capital.

There are several reasons why companies engage in investments in arts. O'Hagan and Harvey (2000) summarize four reasons for art sponsorship. These are: promotion of image/ name; supply-chain cohesion, rent seeking and non-monetary benefits to managers and owners. One may in turn ask what the artist can offer in return to management of companies and non-profit organizations? Art may be created for art's sake or for business' sake. Art may offer creativity which rubs of on organizations that associate with art and creates an association with something more alleviated than the pure commercial aspect of business (Fillis 2002).

While art by many may be seen as a business, people waffle over whether business is an art, as it has to be managed and organized to reach an audience and have an effect on it (Guillet de Monthoux 2005). We see in our research, a close relationship between art and business and that there is a mutual benefit between art and business. Especially does marketing have an essential artistic side, and art can enhance the marketing of businesses. A sharp distinction between the essential and the superfluous, the serious and the facetious, and the scientific and the artistic, has probably lost its legitimacy. At the same time, the sprit between scientific discourse and aesthetic experience has faded (Strati and Guillet de Monthoux 2002). Within this amalgamation of art and science, we have found cultural fields which can be mapped and expressed in geometrical terms. Scientific and artistic discourse merge in the intersections between economic and cultural fields.

\section{Bourdieu's Concepts of Culture}

Pierre Bourdieu introduces novel and compelling concepts that helps analyzing cultural activities and relationships between actors in the intellectual field. Few areas can be seen to demonstrate relational thinking than that of art and literature (Bourdieu 1983, p. 311). Foremost, Bourdieu represents a genuine approach to post-structuralism, as he synthesizes French structuralism, conflict theory and phenomenology (Holt 1997, p. 94). Bourdieu claims that the relationship between the artist and his work within which an act of communication takes place can be described as a position in the structure of an intellectual field. From the positions of cultural actors, positional properties can be derived which corresponds to a specific type of positional properties within the cultural field (Bourdieu 1969, p. 89). Methodologically, Bourdieu's research represents what he describes as a realist construction (Bourdieu 1996b, p. 27). He analyses the interaction between the investigator and the person 
questioned as a communication in its general state where practical and theoretical problems emerge simultaneously (Bourdieu 1996b, p. 17).

What stands in the way for an interpretation of the value of cultural goods and the charismatic ideology of creation? Bourdieu answers this question by introducing the concepts of habitus, capital and field (Hesmondhalgh 2006, p. 212). The definition of a field has been outlined as: "a structured space of positions in which the position and their interrelations are determined by the distribution of different kinds of resources of capital" (Thompson 1991, p. 14). Important to the sociology of cultural production is the idea of autonomy which is central to the account of modern culture-making. Autonomy of art is not a universal condition, but was actively produced in the nineteenth century (Benson 1999, p. 465). What is accumulated by autonomous actors in their habitus is symbolic capital which represents accumulated prestige and honor (Thompson 1991, p. 14).

At the heart of the production of works of art lies competition and struggle where the immaterial production of works of art plays a role in its symbolic production and its passing on of acclamation. In the cultural field, people and organizations struggle for the legitimacy and influence of their judgment. Bourdieu's term habitus represents a system of social and environmental factors as well as dispositions which consciously or unconsciously direct the behavior of those involved (de Glas 1998, p. 380).

\section{The Concepts of Field and Capital}

Bourdieu emphasizes the importance of relationships between social groups (Broady 1991) and believes that there is a social dimension in both consumption and production (Bourdieu 1986a, b; Bourdieu 1992; Bourdieu 1979/2004; Broady 1991). Regarding companies operating in Sweden, we can therefore distinguish between production fields and consumption fields. Within the field of production there are those actors, organizations and institutions that create tangible and symbolic assets, for example those that produce materially measurable goods and services, as well as those that create immaterial goods with indirect or symbolic value. In this study a specimen, a section or a segment of the Swedish production field of profit-oriented companies that have relationships with a section of the Swedish production field of non-profit oriented organizations in the field of art are studied. The term specimen or segment is used partly to emphasize that it does not involve a complete study of the production fields. If no fullscale field according to Bourdieu's definition exists, instead, the term "field-like" space or room can be used. However, this room requires a structure of field-like positions. One could consider a social field or social room as a data projection conducted with correspondence analysis. The close link between theory and method is most probably the reason why Bourdieu himself used almost exclusively correspondence analysis as his main statistical method (Postone in Bourdieu 1993a, p. 11). This paper thus studies a specimen or a segment of the production field, defined as a "field-like" room with correspondence analysis. Furthermore, we have been inspired by Bourdieu's theories and terminology thus working in a spirit of Bourdieu. Bourdieu believes that his theories and methods are not static, instead, he suggests that these should be adapted and changed relatively freely for new research areas (Bourdieu from Bourdieu 1993a, p. 271).

The phenomena to be studied are the allocation and the concentration of capital in Bourdieu's sense, i.e. a set of tangible assets among the profit-oriented businesses as size, industry, and board composition, and the symbolic assets in terms of relationships with non- 
profit oriented companies in the art field. Also the profit-oriented businesses' art possessions that are exposed publicly on the premises or art possessions that are reported in annual reports or made publicly known otherwise are studied. In this way a mapping is made possible of different distributions of material and symbolic capital where diverse assets also result in different symbolic assets. Thus different social clusters of consumption and production are symbolic and both unite and differentiate. Any field is a battle field where fighting is about something that unites the actors on the field. Actors can compete for the same kind of production that is going on in the field or the symbolic assets, i.e. the types of profit oriented companies that have established relationships with the nonprofit oriented companies in the art field. Bourdieu's theoretical concept then becomes essential to study the different actors' relationships and to study the fight or at least the hierarchy of the field.

In a field there may be existing organizations or specific actors. These actors are giving different phenomenon value. Value that can be used by actors in a specific field. These organizations are generally accepted by the actors in the field. The organizations contribute to the establishment or definition of value in the field. Such organizations are usually referred to as consecration organizations. The Museum of Photography and Carnegie Art Award would be examples of such organizations that help to create artefacts or phenomena defined as art on the art field.

The concept of field is used in this context for reasons of convenience, whereas a more correct term would be a "field-like" room, or a room of field-like-character. The empirical data is in three different sections: i) the production field for profit-oriented companies, ii) the production field for non-profit oriented organizations in art, iii) the consumption field for profit-oriented companies of art, i.e. the profit-oriented businesses' art possessions.

\section{Methodology}

Correspondence Analysis, which is a somewhat simpler method than multiple correspondence analysis, are both types of factor analysis, however, with the ability to include non-hierarchical data. The method can include a multitude of data in the analysis and visualizes the results. Correspondence analysis is based on variations in the data. The more extreme an attribute is, the further away from the middle of the figure a variable category is found. Variable categories are usually called modalities in the correspondence analysis. Any "normal" modality in the data material is placed in or near the center of the figure called barycenter. The axis measure geometric chi2 values, i.e. distance from the barycenter. The first axis measures the largest variance in the data, the other axis measures next most, the third axis third most, etc. in decreasing importance for the explanation of what the axes measure. The position in the figure for any modality is determined by how much this specific modality deviates compared to the other modalities in the data material. The higher the number on an axis a modality receives as its figure position, i.e. further away from the barycenter, the more abnormal the modality is compared to the expected or normal position for modalities in the data. The modalities define what the axis measure and must be interpreted by the analyst (Le Roux and Rouanet 2004; Lundin 2005).

Correspondence analysis and multiple correspondence analysis have been extensively used by the French sociologist Professor Pierre Bourdieu. Bourdieu let his conceptual apparatus to be part of an almost symbiotic relationship with this methodology (Broady 1991). The method was used in La Distinction, which made Bourdieu known to a wider public, particularly after 
the study was translated into English under the title Distinction (Bourdieu 1979/2004). A consequence of this is that the concept of field or room would be difficult to analyze using other methods of analysis than correspondence analysis. In Bourdieu's theories the concept of field or room is central. The field describes the relationship between the characteristics of the actors and this fact has been assumed in the analysis in this study.

Bourdieu's concept is based on tastes or preferences. Preferences are expressed as specific attributes of the various societal participants that both unite and differentiate regarding any specific phenomenon, such as a market for art production, where the market can be considered from a consumer or a producer perspective (Bourdieu 1979/2004; Bourdieu 1992; Bourdieu $1996 \mathrm{a}, \mathrm{b}, \mathrm{c}, \mathrm{d})$. Bourdieu analyzed many phenomena or contexts such as academia in the work of Homo Academicus (Bourdieu 1996a, b, c, d), or the training of policy makers or elite administrators to the French public sector in State Nobility (Bourdieu 1996a, b, c, d/1998). What unites these works is a purpose and a method of analysis to identify different groups. In the above mentioned works the analysis method is not always a fully performed correspondence analysis, but the way of thinking is the same. The idea of attributes that unite and differentiate can even be carried out manually (Bourdieu 2000). A perspective that unites and distinguishes groups, individuals or actors is thus fundamental. In analogy with the unifying part of the concept, there are also predispositions that repel individuals or actors from each other such as dislike or disgust for other individuals' or actors' tastes or preferences. Like and dislike can thus identify clusters or groups of actors that have something in common and that simultaneously distinguish them from other groups. Hereafter, the term preferences will be used for reasons of simplicity. Preferences acquired in accordance with Bourdieu's theories either by inheritance or environment are often, but not always, unknown to the actor. Fundamental concepts in Bourdieu's theories are field, habitus and capital. Capital can be in the form of material, such as financial capital or symbolic capital such as cultural capital.

The empirical data in this study may be considered as a production field according to Bourdieu's perspective, where actors' preferences are expressed in various actual attributes. These attributes are, among others, associates to the non-profit oriented art market. This market will henceforth be called field and the attributes considered as capital, which represent different actors' ways of positioning themselves in this field. There are vital similarities with this perspective and Bourdieu's earlier studies such as Distinction (1979/2004). However, the similarity in itself is of secondary importance, as Bourdieu himself claimed that his theories were intended to be used in new contexts and in new ways (Bourdieu and Wacquant 1992) and are not intended to be slavishly repeated in what Bourdieu himself did in his studies or in the contexts Bourdieu chose to collect empirical data from. Bourdieu's theories, concepts and perspective are thus intended to be used on new empirical data and in new contexts. The purpose of this study is therefore to apply Bourdieu's theoretical concept and the method that was so often used by Bourdieu in a new Swedish context. The method of multiple correspondence analysis has been used in a Swedish business context before (e.g. Borg and Vigerland 2013) and Bourdieu's theoretical concept combined with this method has previously also been used in a Swedish business context (Vigerland 2007). Bourdieu's theoretical concept combined with multiple correspondence analysis is not widely used in the interface between business and art. However, Bourdieu uses correspondence analysis, not least in his book Distinction (Bourdieu 1986a, b) where he lists as variables several cultural dimension such as modern art museums, abstract and impressionist paintings as well as specific painters such as Kandinsky. These dimensions are related to capital and is therefore related to what we have described as business related dimensions of the production and consumption of art. 


\section{Data}

The empirical data consists of profit-oriented companies operating in various lines of business, and these companies' relationships or connections to non-profit organizations in the production of art and these companies' art possessions. A summary of the profit-oriented companies in various lines of business is shown in the table below. The chart shows that various lines of business exist, such as law firms, banks, investment banks and manufacturing companies. It is noteworthy that galleries, art business and auction houses are included. Galleries, art business and auction houses are certainly active in the arts industry, but the essence is that these companies are profit oriented and have at the same time any type of connection to nonprofit enterprises in art production. Thus, there are two main groups: companies with profitoriented goals in various lines of business, also including art production, and companies or organizations, whereby for example foundations are included, with non-profit oriented goals engaged in different kinds of art production. The objective in this study is to map and analyze the profit-oriented companies' relationships or connections to the art market where art itself is in focus. Art was defined very widely and includes all types of artistic activities such as painting, theater, opera, writing, installations, etc (Table 1).

\section{The Anatomy of an Economic Field}

The economic field of the profit-oriented businesses are shown in Fig. 1. The figure is a barycentric chart and is a visualization of the multiple correspondence analysis. This figure represents a section of the production field of the profit-oriented corporations with attributes from the production field of art of non-profit oriented organizations and the consumption field of art of the profit-oriented corporations.

The material includes 108 profit-oriented companies and 43 non-profit oriented organizations with different kinds of art activities. The fact that the non-profit oriented companies operating in different types of artistic activity in itself is significant, because different profitoriented companies have different opportunities or susceptibility to various strategic relations in the art field. Altogether 8 active variables with 27 variable categories, or modalities that it is referred to as in the correspondence analysis, and 7 inactive, illustrative or supplementary variables as it is referred to in the correspondence analysis, with 76 modalities have been used in the analysis. The active variables consist of data of i.) turnover, ii.) line of business, iii.) year of establishment, iv.) ownership, v.) membership of any member of the board to any established gentleman's club, vi.) any member of the board being a well-known individual

Table 1 Organizations participating in the study

\begin{tabular}{llllll}
\hline & Frequency & Percent & Valid percent & Cumulative percent \\
\hline Valid & Law firm & 5 & 4,6 & 4,6 & 4,6 \\
& Auction house & 7 & 6,5 & 6,5 & 11,1 \\
& Gallery/Art firm & 14 & 13,0 & 13,0 & 24,1 \\
& Bank & 8 & 7,4 & 7,4 & 31,5 \\
& Inv. bank & 25 & 23,1 & 23,1 & 54,6 \\
& Prod./Other & 49 & 45,4 & 45,4 & 100,0 \\
& Total & 108 & 100,0 & 100,0 & \\
\hline
\end{tabular}




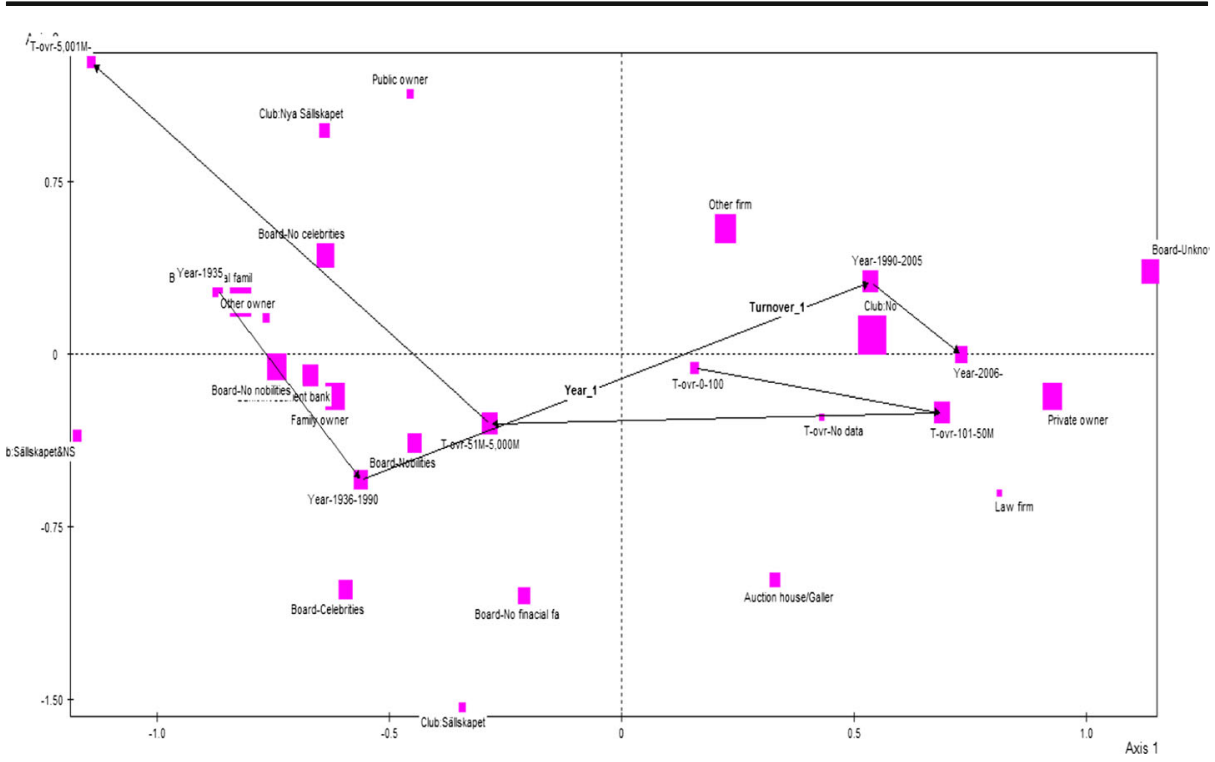

Fig. 1 A visualization of the field of the profit oriented companies showing some attributes, i.e. some active variable categories (modalities). To clarify the structure of the field the variable categories of turnover and age of the companies have been linked together with arrows. Please note that young companies with low turnover are oriented to the right side of the graph $(+, 0)$, and that old companies with high turnover, the opposite kind of companies, to the top left corner $(-,+)$

(celebrity), vii.) any member of the board belonging to a well-known financial family, viii.) any member of the board belonging to a family of nobility. The seven illustrative variables contain information about any direct or indirect links to the art field. This link maps via the board members any established cooperation with or association to actors active in the art field. One of the illustrative variables also contains information from the consumption field of art, i.e. art possessions of the profit-oriented companies such as older oil paintings, modern art and photography.

The analysis shows that there is a division between the profit-oriented businesses based on size. There are essentially three different polarities which are shown in Fig. 3. In order to facilitate the comments of the various parts of the figure it is necessary to identify different positions in the figure so that the designations,+ 0 and - are used for each axis, so that the first term refers to the position of axis 1 and the second term to the position on the axis 2 . In this way the figure is divided into different parts. Position designation $(+,+)$ thus means the upper right corner, $(+, 0)$ means the right part of axis $1,(+,-)$ means the lower right corner $(0,-)$ means the lower part of axis 2, etc. The clusters or polarities labelled 1,2 and 3 are located from the left side of the figure to the right, which can be seen in Fig. 3. Polarity 1 is oriented toward the left side of the figure or rather the field with the center in the upper left part of the figure $(-,+)$. This polarity incorporates 56 companies. Polarity 2 is oriented toward the lower left part of the field $(-,-)$ and this polarity incorporates 15 companies. Polarity 3 is oriented toward the upper right part of the field $(+,+)$ incorporating 37 companies. These three polarities include all profit-oriented companies in the data set of 108.

Axis 1 measures mainly company size and year of establishment of the profit-oriented businesses; axis 2 measures line of business and the composition of the board, while axis 3, which is not shown in Fig. 1, measures ownership and characteristics of the board. Thus axis 1 
measures company size, while both axes 2 and 3 provide additional and more detailed information. A more detailed description of the field (Fig. 3) shows that the big companies, including large turnover can be found in the upper left corner $(-,+)$ and the smaller companies in the right part $(+, 0)$. Medium-sized companies are found in the field's lower left $(0,-)$. Similar hierarchical distribution is also apparent in other variable categories so that the oldest companies can be found in the upper left corner $(-,+)$ and the youngest in the right part $(+, 0)$. Directors of large companies are to a greater extent associated with gentlemen's clubs. Belonging to a gentlemen's club provides members to valuable networks and an opportunity to influence members from other parts of society as well as other companies and business partners.

In a Bourdieu-perspective, the big companies represent the field's dominant participators with large economic capital. The economic capital consists of high turnovers and established positions, partly due to the longer time span the older companies have been in operation, while the smaller companies hold less economic capital and lack an established position that a longterm business reputation provides. The big companies also have symbolic capital, recognized as some board members belonging to established networks through gentlemen's clubs. These gentlemen's clubs have a formalized election process in which the candidate must be proposed. Admission and membership is often based on professional success, an influential social position or affiliation to a known and established family. This would in a Bourdieuperspective be known as consecration-process, where testing is done by legitimate members who meet certain pre-established requirements and that serve as the guarantor of a particular social position. Membership of these clubs is exclusive in the sense that it is not accessible to anyone. Membership to a gentleman's club provides the company with a good reputation via the board member. Thus symbolic capital is created for the organization associated to the member. Memberships of gentlemen's clubs are oriented mainly towards the left part of the field where the large and medium-sized companies are found. In this part of the field there are also companies with board members from established and influential families. Bourdieu would call these senior families, i.e. families that have belonged to high societal positions for many generations. In this case a particular family name provides a symbolic capital. In the opposite polarity of the field there are companies that could be called the dominated or some of them possibly the challengers (avant garde). The challengers are the companies that are about to be established and that relatively recently started to develop a growing reputation in business. This part of the field is characterized by an absence of, or at least a limitation, of economic capital as well as an absence of symbolic capital in the form of club affiliation between board members and a lack of board members belonging to an established or known family.

\section{The Anatomy of a Cultural Field}

The cultural field consists of some of the inactive variable categories, or the illustrative modalities. These must be understood in relation to the structure of the field of the profitoriented companies. Examples of art organizations associated with big companies, in the field's upper left, is Sven Harry's Art Museum, Carnegie Art Award, Opera Initiative and Magasin 3 / Stockholm's Art Hall. The art exhibition hall Artipelag is oriented towards medium sized companies, while the Museum of Photography is oriented toward small companies (Figs. 2 and 3). Photography as art possessions is oriented toward the cluster of the small companies. 




Fig. 2 A visualization of the field of art showing some attributes (inactive modalities) of the not for profit art organizations, showing that Carnegie Art Award, Magasin 3/Stockholm Art Hall and Sven Harry's Art Museum are oriented toward large companies, traditional and modern art possessions are oriented toward mid-size companies and Museum of Photography as well as photo as art possessions are oriented toward small companies

The profit-oriented companies in the arts industry as auction houses and galleries are associated with photography as an art form and the Museum of Photography in the art field. The connection to the Museum of Photography can be largely explained by the auction house Bukowski with its informal cooperation with the museum. These profit-oriented companies are oriented toward the polarity of the small companies. In this part of the field also law firms, manufacturing companies and other companies can be found. Traditional art is oriented toward the center of the field, which means that this type of art possession is not characterized by any

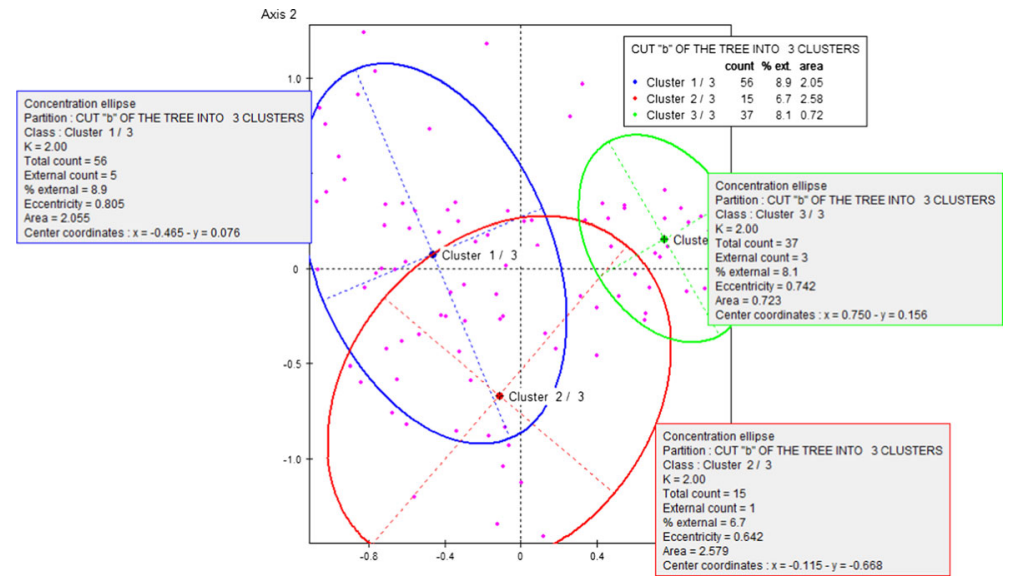

Fig. 3 A visualization of the cluster analysis of three clusters, where only some of the characteristics of the clusters are mentioned; 1: bank/investment bank, member from established financial family on the board, dominant family owner, high turnover, person on the board belonging to gentlemen's club Sällskapet and/or Nya Sällskapet, 2: medium turnover, person on the board belonging to gentlemen's club Sällskapet, 3: unknown board members, private owner, person on the board belonging to no gentlemen's club 
type of divergence in data, i.e. it is main stream art. Modern art is oriented toward small companies, while both traditional and contemporary art possessions are oriented toward medium-sized companies.

\section{Specimen or Segments from an Economic Field and from a Cultural Field}

The attributes of the profit oriented companies in relation to the non-profit oriented art organizations are important for the structure of the field, whether the attributes are mainly developed and chosen by the commercial companies themselves, by the arts organizations, or by both in collaboration.

It is possible to identify a field structure in accordance with Bourdieu's theoretical framework, where there is a hierarchy and a power structure with actors. The companies are characterized by different accumulation of economic capital and different time since establishment. The hierarchy ranges from the upper left corner with the dominating actors through the lower left corner of actors with intermediate positions to end up in the upper right corner of the dominated, or some even challengers on the field structure and field characteristics. Whether those companies that are at this moment in this sample dominated or challengers only the future can tell. The challengers are the companies that struggle to assume future dominant positions. Among the companies that currently occupy positions in the dominant part of the field, there are probably some companies that will occupy dominant positions in the future and some dominated. A different field structure can come about by acquiring or loosing economic capital to the extent that these companies change from the position of dominated to the position of dominating or vice versa. Companies' revenues are a significant part of their economic capital. Although the year of establishment naturally is important for the accumulation of economic capital, it is also important for non-material capital, i.e. a kind of symbolic capital. An old year of establishment normally creates something positive for the brand value. Symbolic capital is another name in this context for brand value, more in line with Bourdieu's conceptual framework.

The cooperation and the relationships with non-profit arts companies provide symbolic value to the profit oriented companies. These relationships are like the preferences described in different works by Bourdieu (e.g. Bourdieu 1979/2004). These relationships constitute attributes associated with specific positions in the field. The dominated, or actors with late year of establishment, and with low turnover are associated with attributes such as photography. Attributes associated with traditional and contemporary art possessions are located in middle positions. These actors are to some extent related to photography, like the Museum of Photography. There are thus some modalities that to some extent are in common for both the middle position and for the dominated position.

The large and established companies consist of categories like "investment banks". One of these investments banks is Carnegie with relations to "Carnegie Art Award". This award can be regarded as a strategy for e.g. the investment bank Carnegie to participate in the legitimization of art. This relatively large and more than 200 year old investment bank, thus with a large amount of symbolic capital, has direct links to and power over the Carnegie Art Award, which would be regarded as cultural capital.

From a Bourdieu-perspective the investment bank Carnegie belongs to the dominant part of the economic field. By active participation in the art field, Carnegie takes part in a legitimation of specific works of art and artists. The Carnegie Art Award is an institution that cannot be 
ignored in the Swedish art field. It is a so-called consecration organization with a purpose to provide hallmarks to point to the legitimate art, the art to be given value on the art field. Carnegie's economic capital also manifests itself in the economic values of the Carnegie Art Award. The Carnegie Art Award prize competition among contemporary Nordic artists provides a first prize of 1 million SEK (ca 120,000 \$), the second prize of 600,000 SEK (ca $70,000 \$)$ and the third prize of $400,000 \operatorname{SEK}(50,000 \$)$. The prize money is in an art context unique and is the highest prize in Scandinavia. The prize winners also participate in an exhibition tour of the Nordic capitals (Carnegie Art Award 2015). For the artists the price thus also gives an important opportunity for promotion, even though the artists themselves hardly would express themselves in those terms (Gustavsson et al. 2012).

The Carnegie Art Award is however not entirely uncontroversial. There is a struggle for the legitimate consecration organizations that charges art, artworks, and artists with value that is viable in the art field. The fight for legitimate value of the specific field is symptomatic of the struggle that prevails on any field. The Carnegie Art Award prize has been talked about in the art field as vulgar and it has been perceived as absurd that an investment bank would have the ability to participate in the art field's affairs. When the prize was introduced in 1998 it was criticized for being vulgar. However, as time went on most of the criticism has declined. One important reason for this is most probably the fact that the members of the jury are selected among established artists from the art field itself. Today, the Carnegie Art Award is one of the important institutions in the Swedish art field (e.g. Stockholm 2014; Lenas 2014; Konsten.net 2012; Vilks.net 2011). The investment bank Carnegie donates money and supports operations in the Carnegie Art Award, but interferes in no way in its work, which most probably is a very informed choice. The Carnegie Art Award is a very obvious relationship and cooperation, even partnership, between two very different production fields, the economic field, on the one hand and the art field on the other. On the basis of field logic such cooperation is however not without challenges.

The economic field has its logic with intrinsic values consisting of, for example, revenue generating economic capital, while the art field considers questions such as what constitutes good art. The art field is also involved in definitions of art from the perspective of different activities such as visual art, video art, performance art, etc. The art field is most probably significantly more sensitive to "contamination" from the economic field than vice versa. An artist who is too commercial will face difficulties in being accepted as a good artist and thus face difficulties in accumulating any value that is recognized as important and appreciated in the art field. (Gustavsson et al. 2012) Values in the art field are essentially symbolic, while values in the economic field are essentially material. Carnegie is located in one of the three polarities of the field where art is defined by a Carnegie associate, its partner Carnegie Art Award in the art field. The Carnegie Art Award is undeniably an important institution in the art field and Carnegie is a major player in the economic field.

A dependence on strong owner families becomes apparent in the field in variable categories such as board composition and dominant owner families. These categories are mainly oriented towards the polarity with large companies. A heterogeneous board composition is oriented toward the large company cluster.

The second polarity, which occupies an intermediate position between the other two polarities or clusters, is characterized by more modest efforts in the art field. This cluster is associated with art possessions that are relatively traditional, i.e. traditional and contemporary 
art. This intermediate position excels neither in the art field nor in the economic field. The actors in this cluster adopt a cautious approach and it is as consumers of art that they act in the field of art.

The third polarity is associated with small companies that have applied a strategy to place photography as a fully legitimate art form among the more traditional art. In that perspective some of the smaller companies will be the future challengers of art. Although photography in most sets is regarded as an acceptable form of art, it can still be regarded with some reluctance. The challengers redefine the field structure and in this case the definition of art. Photography as a relatively new art form have some substantial resources from companies such as the auction house Bukowski and the oil company Vostok Nafta. The consecration of art can be handled through an institutionalization as the example of Carnegie and Carnegie Art Award for modern yet mainly traditional art, and on the other hand the Museum of Photography which aim to launch and establish the relatively new art form. Photography, as a somewhat less expensive form of art possession is oriented toward small companies. It is worth noting that no identified art possessions are oriented toward the absolute field center (i.e. the barycentric center of the figure).

The Museum of Photography and Bukowski have a direct need for each other. Photography as an art form is relatively new as stated before. To establish this new art form as acceptable in the art field, it is important to introduce photography as art, for instance by creating similar institutions as in other art forms. The Museum of Photography is an institution of consecration for photography, just as Carnegie Art Award is an institution of consecration for more traditional art. The Museum of Photography is therefore part of a strategy to transform photography from a way to preserve family memories only to an established and recognized art form. The Museum of Photography was established in 2010. On the homepage it is indicated that the museum has a bright future and that photography is an art form for everyone. (Fotografiska 2015) The auction house Bukowski is in this context the profit-oriented organization that has directly benefited from the establishment of photography as an art form. In recent years, sales of photography has increased considerably at Bukowski auctions. If photography would not be defined as art, it could naturally not be for sale at the auctions at Bukowski. Thus the Museum of Photography is important for Bukowski to define photography as a recognized and legitimate art form, something that contains value on the art field. Accordingly the Museum of Photography is in need of Bukowski. Photographs traded at the Bukowski auctions fetch considerable amount of money and should thus be accorded a symbolic, cultural value. This cultural capital is the cornerstone of the museum's entire existence.

A systematic way to analyze the material and its polarities is to conduct a cluster analysis. The principle behind this analysis is to find characteristics of the companies for a predetermined number of subsets. The cluster analysis that is displayed below confirms the three polarities of the correspondence analysis.

\section{Conclusions}

Bourdieu has been considered to be perhaps the most influential social theorist of the second half or the twentieth century (Throop and Murphy 2002). He has made profound contributions to both philosophy and sociology. His formal educational training was in philosophy, and not in sociology or anthropology (Robbins 2002). Bourdieu fought with all means against the neo- 
liberal turn, and had a focus in his work on social practice (Callewaert 2006). Some of his key concepts were habitus, misrecognition and the logic of practice, and his vision of tacit knowledge represents knowing how as supposed to knowing that (Gerrans 2005). Bourdieu's notion of strategy breaks with the objectivist point of view, and the notion of agentless action that is common within structuralism (Lamaison and Bourdieu 1986).

We have in our research explored the intersection between art and business. By involving an aesthetic dimension to organizational research we are challenging the boundaries between art and business. Although there are geometrical and mathematical dimensions in our methodology, the approach is interpretive. All the dots and clusters in our figures are related to individual actors. There are actors behind every geometrical expression and they can be interpreted individually. Art in our study is interwoven in the enterprises that deal with art. Their relationship to art is not superfluous, facetious or merely purely artistic. The results bridge the gap between structure and agency. Actors in the cultural field are interacting and relating to each other and are not merely part of a structure. We make a distinct contribution to art marketing, as art is reaching its audience in conjunction with the activities of the art actors we have identified. Social inclusion is a central dimension of the cultural field. Consumption of art provides meaning and identity and enhances the very definition of organizations that are engaged in the cultural field.

In our conceptualization of art marketing, art has become more accessible to people and in new contexts. Social inclusion, community development and urban regeneration take place as investors in art and make art more reachable within individuals' habitus. By increasing their social capital, individuals and enterprises evolve an aesthetic strategy. In this strategy, individuals become agents of aesthetic expression and are not merely embedded in a new cultural structure. When corporations use art, new consumers of art can be reached and businesses enhance their cultural and economic capital.

The fields of art and its relationship to economic capital is constantly evolving. Photography is, for instance, gaining a more prominent position within traditional art. In the Social definition of photography, Bourdieu (1999) saw a development from the view of photography as closely associated with relationships within the family. Family portraits dominated the early use of photography as an artistic medium. Later, photography has risen within the ranks of fine art and is accepted as a form of artistic expression by many. Photography has become more traditional and mainstream. We have followed the dynamics of the art field as investors in art and the art business field has developed. Artists and investors in art are more acutely aware of the economic dimensions of art. This tendency is likely to persist as more art is sold via the Internet and thereby has an electronic field of art rapidly developed. Cultural production in Stockholm is becoming more accessible to a broader specter of society. A more computersavvy audience is entering the art market. Politically, there has been a movement to accommodate the new expressions of art not least that which is exhibited in the public domain. At the same time the not-for-profit investors have been keen to embrace the former low brow arts.

With multiple correspondence analysis a field and its structures has been produced. The field, or rather a specimen of a field, of profit-oriented companies and their links to organizations on the production field of art as well as their links to the consumption field of art has been produced. The field consists of three clusters or polarities. The first cluster of these three consists of the dominant, i.e. companies with large financial capital (turnover $>5,000,000,000$ SEK) and large symbolic capital in the form of an early year of establishment (before 1935). These companies are also characterized with board members belonging to important networks such as membership in certain gentlemen's clubs. Certain boards have members belonging to 
both gentlemen's clubs in Stockholm. Membership of these publically closed clubs provides both access to informal networks and conveys a certain symbolic capital to the board and also to the company. This first polarity also includes directors stemming from financially recognized and established families as well recognized and established individuals or celebrities from the world of business. These well-known people on the boards are likely to contribute valuable knowledge to the businesses that can be converted into clever decisions, but they also contribute to the symbolic capital, i.e. an aura to the board and thus to the company, contributing symbolic capital. This cluster is also associated with private ownership, which means that companies predominantly have clear dominant private owners.

The next cluster consists of companies that, in this context, show an intermediate position in terms of sales (51 million SEK $\leq$ turnover $\leq 5.000,000,000$ SEK) and year of establishment (1936-1990). These facts result in an intermediate position regarding economic capital. There are elements of club affiliation, membership is however dominated by the somewhat less exclusive club of the two. There are some wellknown personalities among the directors within the boards of the companies of this second cluster. The directors' club affiliation as well as elements of celebrities among the board members represents a symbolic capital. However, there are signs that the symbolic capital is of a somewhat subordinate character compared with companies in cluster one. Art possessions among the companies in the intermediate position number two are traditional and modern art. These possessions consist of conventional art and the companies participate on the field of consumption of art. However, there is nothing among these companies that identifies activity on the production field of art, as could be found in cluster one with the relationship between the investment bank Carnegie and its associate Carnegie Art Award on the production field of art.

Finally in cluster three, there are those companies dominated by low economic capital (turnover $\leq 50$ million SEK) and low symbolic capital in the form of a late year of establishment (before 1990). Among the companies in this polarity of the dominated, there is most probably a number of companies that will gradually accumulate more financial capital and thus move from at present a dominated position into a dominant one. These companies are referred to as challengers, as they challenge the existing incumbents. The striking thing about the dominant in cluster three is the absence of symbolic capital as recognized personalities on the boards. The relationships in this cluster with the production field of art is the Museum of Photography.

Given that some of the dominated companies will continue challenging the dominant companies both in the economic as well as in the cultural field regarding photography as a legitimate art form and in their art possessions, photography as an art form will no longer be associated to dominated positions. Photography as an art form will thus possibly take a more established position. It has already been successfully launched and substantial bodies already exist for consecration such as the Museum of Photography and Bukowski for commercial sales. The economic field and the art field have usually been regarded as two very separate and different fields. The art field's logic is perceived as especially sensitive to contamination of the logics of the economic field. With a possible closer cooperation and engagement or even an inter-dependency in the future, the so far distinct field logics will be less so. The economic field is intense depending on the easy transformation of economic capital to other forms of capital, unlike cultural capital that requires a long-term accumulation of the non-material value. In the event of a rapprochement between the economic and the cultural fields, the economic field has a potential of dominating the art field. 
Open Access This article is distributed under the terms of the Creative Commons Attribution 4.0 International License (http://creativecommons.org/licenses/by/4.0/), which permits unrestricted use, distribution, and reproduction in any medium, provided you give appropriate credit to the original author(s) and the source, provide a link to the Creative Commons license, and indicate if changes were made.

\section{References}

Archer, M.S. 2000. Being human: The Problem of Agency. Cambridge: Cambridge University Press.

Benson, R. 1999. Field theory in comparative context: A new paradigm for media studies. Theory and Society 28: 463-498.

Biel-Missal, B. 2013. The atmosphere of the image: An aesthetic concept for visual analysis. Consumption, Markets \& Culture 16 (4): 356-367.

Borg, E., and L. Vigerland. 2013. The co-production of value in an art market - Exploring service networks. Journal of Investment and Management 2 (3): 57-69.

Bourdieau, P. 1999. The social definition of photography. In Visual culture: The reader, ed. J. Evans and S. Hall. London: Sage.

Bourdieu, P. 1969. Intellectual field and creative project. Social Science Information 8 (3): 89-119.

Bourdieu P. 1979. Symbolic Power. Critique of Anthropology 4 (13-14): 77-85.

Bourdieu, P. 1983. The field of cultural production, or: The economic world reversed. Poetics 12: 311-356.

Bourdieu, P. 1986a. Distinction: A social critique of the judgment of taste. London: Routledge \& Kegan.

Bourdieu, P. 1986b. Kultursociologiska texter. Stockholm: Brutus Östlings bokförlag.

Bourdieu, P. 1992. Texter om de intellektuella. Stockholm: Brutus Östlings bokförlag.

Bourdieu, P., ed. 1993a. Critical perspectives. Polity Press: Cambridge.

Bourdieu, P. 1993b. The field of cultural production. New York: Colombia University Press.

Bourdieu, P. 1996a. The Rules of art. Stanford: Stanford University Press.

Bourdieu, P. 1996b. Understanding. Theory, Culture and Society 13 (2): 17-37.

Bourdieu, P. 1996c/1998. Homo Academicus, the state nobility: Elite schools in the field of power. Cambridge: Polity Press.

Bourdieu, P. 1996d. Homo Academicus. Stockholm: Brutus Östlings bokförlag.

Bourdieu P. 1999. The Social Definition of Photography. In Visual Culture: The Reader, eds. J. Evans and S. Hall, London: Sage.

Bourdieu, P. 2000. Konstens regler: Det litterära fältets uppkomst och struktur. Stockholm: Brutus Östlings bokförlag.

Bourdieu, P., and L.J.D. Wacquant. 1992. An invitation to reflexive sociology. Chicago: Chicago University Press.

Broady, D. 1991. Sociologi och epistemologi: Om Pierre Bourdieus författarskap och den historiska epistemologin. Stockholm: HLS Förlag.

Callewaert, S. 2006. Bourdeau, critic of Foucault, the case of empirical social science against double-gamephilosophy. Theory, Culture \& Society 26 (6): 73-98.

Carnegie Art Award. 2015. www.carnegie.se/en/carnegie-art-award/about-the-carnegie-art-award/.

Charters, S. 2006. Aesthetic products and aesthetic consumption: A review. Consumption, Markets \& Culture 9 (3): 233-255.

De Glas, F. 1998. Authors' oeuvres as the backbone of publishers' lists: Studying the literary publishing house after Bourdieu. Poetics 25: 379-397.

Fillis, I. 2002. Creative marketing and the art organisation: What can the artist offer? International Journal of Nonprofit Voluntary Sector Marketing 7 (2): 131-145.

Fotografiska. 2015. www.fotografiska.eu.

Fowler, B. 1996. An Introduction to Pierre Bourdieu's 'understanding', Theory. Culture and Society 13 (2): 1-16.

Gerrans, P. 2005. Tacit knowledge, rule following and Pierre Bourdieu's philosophy of social science. Anthropological Theory 5 (1): 53-74.

Giddens, A. 1984. The construction of society: Outline of the Treory of Structuralisation. Cambridge: Polity Press.

Guillet de Monthoux, P. 2005. Mono management: A note on the insulant Antonin Artaud and his clients. Culture and Organization 11 (4): 259-268.

Gustavsson, M., M. Börjesson, and M. Edling. 2012. Konstens omvända ekonomi: Tillgångar inom utbildningar 1938-2008. Stockholm: Bokförlaget Daidalos.

Hesmondhalgh, D. 2006. Bourdieu, the media and cultural production. Media, Culture and Society 28 (2): 211-231.

Holt, D.B. 1997. Distinction in America? Recovering Bourdieu's theory of tastes from its critics, Poetics 25: 93-120.

Joy, A., and J.F. Sherry. 2004. Framing considerations in the PRC: Creating value in the contemporary Chinese art market, Consumption. Markets \& Culture 7 (4): 307-348. 
Kerrigan, F., D. O’Reilly, and D. von Lehn. 2009. Producing and consuming arts: A marketing perspective, Consumption. Markets \& Culture 12 (3): 203-207.

Konsten.net. 2012. www.konsten.net.

Lamaison, P., and P. Bourdieu. 1986. From Rules to strategies: An interview with Pierre Bourdieu. Cultural Anthropology 1 (1): 110-120.

Le Roux, B., and H. Rouanet. 2004. Geometric data analysis: From correspondence analysis to structured data analysis. Dordrecht: Kluwer Academic Publishers.

Lenas, S. 2014. Carnegie Art Award försvinner. Dagens Nyheter.

Lundin, S. 2005. Korrespondensanalys: Rapportering från en kurs. Uppsala: Pedagogiska institutionen, Uppsala universitet.

Merquior, J.G. 1985. Foucault. Berkeley: University of California Press.

O'Hagan, J., and D. Harvey. 2000. Why do companies sponsor art events? Journal of Cultural Economics 24: 205-224.

Özbilgin, M., and A. Tatli. 2005. Understanding Bourdieu's contribution to organization and management studies. Book Review, Academy of Management Studies 30 (4): 855-877.

Robbins, D. 2002. Sociology and philosophy in the work of Pierre Bourdieu, 1965-75. Journal of Classical Sociology 2 (3): 299-328.

Schroeder, J.E. 2006. Aesthetic awry: The painter of light and the commodification of artistic values, Consumption. Markets \& Culture 9 (2): 87-99.

Stockholm TT. 2014. Carnegie Art Award upphör.

Strati, A., and P. Guillet de Monthoux. 2002. Introduction: Organizing aesthetics. Human Relations 55 (7): $755-766$.

Thompson, J.B. 1991. Editor's Introduction, in: Pierre Bourdieu, Language and Symbolic Power. Cambridge: Polity Press.

Throop, C.J., and K.M. Murphy. 2002. Bourdieu and phenomenology, a critical assessment. Anthropological Theory 2 (2): 185-207.

Venkatesh, A., and L.A. Meamber. 2008. The aesthetics of consumption and the consumer as an aesthetic subject, Consumption. Markets \& Culture 11 (1): 45-70.

Vigerland, L. 2007. Homo Domesticus: En marknadsanalys av bostadskonsumenters strategier och preferenser. Doctoral dissertation. Stockholm: Företagsekonomiska institutionen, Stockholms universitet.

Vilks.net. 2011. www.vilks.net.

Wacquant, L.J.D. 1989. Towards a reflective sociology: A workshop with Pierre Bourdieu. Sociological Theory 7 (1): 26-63.

Lars Vigerland is Assistant Professor at the School of Business Studies at Södertörn University. Vigerland's research focuses on marketing, networks and Swedish real estate. Vigerland is the director of the board of The Swedish Carnegie Institute, a private, non-profit foundation promoting and conducting research on current issues. Vigerland also writes regular columns on the Swedish real estate market and he is on the Advisory Board of The Swedish Housing Fund, an investment fund on the Swedish property market. Current research projects concerns networks within art and in financial markets.

Erik A. Borg is Professor of Business Administration at the Department of Social Sciences at Södertörn University outside Stockholm in Sweden. He has held visiting positions at the University of Lund and at the Gothenburg School of Economics, and has been Visiting Professor at Long Island University in New York. Professor Borg has published a wide range of scientific articles and books. He was educated at the United World College of the Atlantic, the London School of Economics and Stockholm University. 